\title{
Lead Acid Battery Recycling In India
}

\author{
Sandhya Prajapati \\ $\left(2^{\text {nd }}\right.$ year M.Tech Electrical Engineering, Gobind Ballabh Pant University of Agriculture and Technology \\ Pantnagar, India)
}

\begin{abstract}
Lead Acid battery usage is colossal in railways, transportation, telecommunication, automobiles and many other sectors and is further increasing with solar and wind schemes launched by government. Morethan $50 \%$ of world lead demand is met by the secondary lead production. In a developing country like India instead of having sufficient amount of lead available for recycling we are forced to import it from other countries like Australia, USA and Korea. According to the data available only a fraction of batteries is collected for recycling while proper regulation is there for used battery collection. Retailers collect the batteries by consumerAuthorized smelters get the spent batteries through open auction by Metal and Scrap trading Corporation(MSTC). MSTC is providing limited auction of batteries because the prize quoted by these smelters is quite low which is not profitable to MSTC. Thus because of low battery collection these smelters are working below their full capacity. Even industries prefer to buy lead from the unlicensed unit(backyard smelters), because the cost of secondary lead coming from unauthorized smelters is low as no pollution control equipment is used there which leads to the problem of emission of lead dust, fumes and $\mathrm{SO}_{2}$. This pollutes the ecosystem severely and responsible for health disorders. Waste water from Indian Lead's plant contains 615 times more lead than is permissible under Indian regulation. Thus the present system not only entails for lead import but also leads to environment misbalance. So the regulation is not enough if not implemented properly. Unauthorized smelting should be punishable offence as it is also responsible for several cattle deaths in Delhi.At every step proper data collection should be recorded if not then penalty should be there to avoid black spots. So that the survey of annual reports leads us to overcome problems of existing system and come up with a better recycling system.
\end{abstract}

Keywords: Backyard smelters, Lead poisoning, Lead battery, Recycling,

\section{Introduction}

The battery contains $70 \%$ lead, $20 \%$ acid and $10 \%$ plastic case. In recycling process batteries are broken cover of batteries is removed and acid is drained out for neutralization. Top portion is hammered for shredding of plastic and the lead posts fixed in the top are released. Furnace smelting is done for approximately 5 hours at over $1000^{\circ} \mathrm{C}$ lead and slag is tapped separately. Refining is done by lowering the temperature thereby decreasing the solubility of impurities. Once the lead is purified it is cast into ingots and reused for further purposes.But during this process lead dust and toxic gases released which needs proper filtering. To arrest these dust particles bag filter or filter fabric can be used to collect dust particles. Lead production by recycling requires $5000-10000 \mathrm{MJ} / \mathrm{t}$ while production from lead ore consumes $7000-20000 \mathrm{MJ} / \mathrm{t}$. Thus battery recycling is not only environment friendly job but also economical.

\section{Lead Acid Battery}

Lead acid batteries are the cheapest way to store energy. The construction of lead acid battery has two electrode one is lead $(\mathrm{Pb})$ and other is lead oxide $(\mathrm{PbO} 2)$. These two electrodes are immersed in the solution of water and sulfuric acid ( $\mathrm{H} 2 \mathrm{SO} 4)$. When battery is generating energy, the lead combines with the sulphuric acid to create lead sulphate (PbSO4), and the lead oxide combines with hydrogen and sulphuric acid to create lead sulphate and water $(\mathrm{H} 2 \mathrm{O})$. As the battery is getting discharged lead sulfate build up on the electrode and the water build up in the sulfuric acid solution. When the battery is charged the process reversed and lead sulfate combine with water to build lead and lead oxide on the electrode.

charging:

$2 \mathrm{PbSO} 4+2 \mathrm{H} 2 \mathrm{O} \rightarrow \mathrm{PbO} 2+\mathrm{Pb}+\mathrm{H} 2 \mathrm{SO} 4$

discharging:

$\mathrm{PbO} 2+\mathrm{Pb}+\mathrm{H} 2 \mathrm{SO} 4 \rightarrow 2 \mathrm{PbSO} 4+2 \mathrm{H} 2 \mathrm{O}$

There are two types of lead acid batteries based on their construction method- flooded and sealed. In flooded lead acid battery the electrode is immersed in electrolyte and regular refilling of water is required for proper working. While in sealed lead acid battery the electrolyte is immobilized. 


\section{Global Picture}

In developed country the occupational health and environmental regulatory cost of lead battery recycling is high and ever increasing. It is not profitable for many secondary lead smelters to operate under stringent regulations. Industrialized countries have well organized system for used battery collection. Countries such as Sweden, Germany and Italy operate adjustable levy system which is related to lead price. A levy is imposed on new batteries which are used to fund the collection and recycling process when the lead price is too low to make recycling economical. In US many states have retailers to collect the used battery when consumer purchase new one. Several American states have a cash deposit on new batteries which is refunded after the return of used battery.

\section{Indian Schenario}

In India there is only one primary producer (Hindustan Zinc Limited) and organized secondary producers India Lead Limited with capacity (24000MT), Thrupathy chemicals Limited (10000MT) and Associated Pigments Limited (15000MT). According to Met Trade India in 2007 primary lead production is $50 \mathrm{kt}$ against $228 \mathrm{ktof}$ secondary production supply. The remaining approximately $60 \mathrm{kt}$ of lead consumed by India is imported. Instead of existing primary and secondary production units we are forced to import lead it's not because the capacity of these units are not enough to recycle lead. More than $90 \%$ recycler's unit produce less than 100 tpa lead. This shows that the units are working under capacity. It not only makes the plant expensive but the pollution control units are also not utilized.

\subsection{Battery Collection}

Previously batteries are collected locally and sent to official regional recyclers, but in reality they are routinely broken apart on the street, the acid poured away and the lead extracted for onward sale to unregistered recycling units, because of the cheap labor availability and standard is low in India. Battery Handling \& Management Rules (BHMR), introduced a formal battery collection system by authorizing only some special agents to collect used batteries for recycling, which is not that effective because of belated implementation. Currently the authorized units for battery recycling are 180, with around 860 secondary smelters in operation. Even the battery collectors do not have the proper record if the buyer smelter is authorized or not. Only a small percentage of the total batteries sold are being collected by the manufacturer, and hence only a few manufacturers are able to collect 90 percent of the total batteries sold, desired by law. Major manufacturers are taking small percentage of their sale including Amara Raja (26\%), TAFE (11\%), Tudor (39\%)and GNB (0\%)

OK International launching its Better Environmental Sustainability Targets (BEST) certification program collected the following databy RTIof states have major lead battery manufacturing capacity in India:

\begin{tabular}{|c|c|c|c|c|c|}
\hline Reporting Period & State & $\begin{array}{c}\text { Total } \\
\text { Production of } \\
\text { Lead Batteries }\end{array}$ & $\begin{array}{c}\text { Total collection of } \\
\text { lead batteries }\end{array}$ & $\begin{array}{c}\text { \% Take Back } \\
\text { Regulatory }\end{array}$ & $\begin{array}{c}\text { \% Take Back per } \\
\text { Total Production }\end{array}$ \\
\hline $2007-2009$ & Andhra Pradesh & 3315980 & 826825 & 51 & 175 \\
\hline $2008-2010$ & Delhi & 211822 & 15830 & 7 & 7 \\
\hline $2008-2009$ & Gujarat & 866521 & 539284 & 158 & 214 \\
\hline $2005-2009$ & Haryana & 8517 & 935 & NA & 15 \\
\hline $2008-2009$ & Kerala & 1427 & 478 & 80 & 75 \\
\hline $2007-2010$ & Tamil Nadu & 2384632 & 712456 & & \\
\hline
\end{tabular}

\subsection{Smelting Process}

Authorized smelter with proper facilities of pollution abatement involves a high cost. But if done on a large scale the environmental cost is absorbed. The biggest threat to the battery recycling in India is backyard or unauthorized smelters. As these are quite profitable because no burden of pollution control cost thus low infrastructure cost. It uses mud furnace (bhatti) to recover the lead from used batteries and sold this lead at low rate as compared to authorized smelters so industries prefer to buy lead from these backyard smelters.It encourages this threatening production by risking environment and human life. Thus authorized smelter works at low capacity and not utilized properly. This lead production is not only hazardous but also affect authorized smelters.

\section{India Market Threat}

Several cattle death cases were also there in Delhi because of lead poisoning in the vicinity of unlicensed lead smelting units. After which Delhi Pollution Control Committee (DPCC) closed some 46 illegal units in Delhi owing their status as highly polluting and hazardous. But it is quite difficult to keep a check on the resurfacing of these units as these can be set up within 24 hours with minimum requirement of a stove and a container. New batteries usedleads recycled by backyard smelter don't last long and their life span varies 
between 7-9 month, which not only increases their recycling rate but also increase the environment threat by recycling with unauthorized way.

\section{Legislation}

According to batteries (Management and Handling) Rules, 2001 this is the responsibility of the dealer to ensure proper collection of sold batteries and file the details of sold and collection by customer after every six month. These batteries should be auctioned to the registers recyclers only. State board is the prescribe authority for ensuring compliance of these rules. Central Pollution Control Board (CPCB) publishes the data received by Sate Board annually. Even after 10 years the release of these rules the condition is worse. According to the report of OK Internationals the union government does not even have data regarding state board reports of battery collection and recycling.

\section{Conclusion}

Instead of these existing rules the present condition is pitiful. This shows that implementation of the existing structure is going wrong and urges a strict implementation to avoid the holes; otherwise there is no use of these rules on paper. The data regarding manufacturing, collection and recycling of batteries should be recorded as per rules. Collected data should be analyzed annually for further improvements and penalty should be their if anyone fails for data collection. Unauthorized smelting should be punishable offence. Otherwise the present system is leading to environment pollution and wastage of lead material. This leads us to import the lead again and again because recycling is not done in effective way as it should be to utilize the existing lead material.

\section{References}

\section{Reports}

[1] "Lead Battery Recycling in India"OK International report.

[2] Annual Report of state pollution control board.

\section{Journal Paper}

[3] Vest, H., Fundamentals of the Recycling of Lead Acid Batteries, GATE information service GTZ

[4] Gottesfeld, P. and Pokhrel, A., "Review: Lead exposure in BatteryManufacturing and Recycling in Developing Countries and Among Childrenin Nearby Communities." JOEH, 8:520-532 (2011). 